\title{
O TRÁGICO SOCIAL DO SÉCULO XIX: REPRESENTAÇÃO DAS FIGURAS FEMININAS EM MEMÓRIAS PÓSTUMAS DE BRÁS CUBAS
}

\author{
Evellin Naianna Souza Oliveira Gomes ${ }^{1}$; Flávia Aninger de Barros Rocha ${ }^{2}$; \\ 1. Bolsista PIBIC-Af/CNPq, Graduando em Licenciatura em Letras Vernáculas, Universidade Estadual de Feira de \\ Santana, e-mail: evellinoliveirag@gmail.com \\ 2. Orientador, Departamento de Letras e Artes, Universidade Estadual de Feira de Santana, e-mail: \\ flavianinger@gmail.com
}

PALAVRAS-CHAVE: Tragicidade; Machado de Assis; Memórias Póstumas de Brás Cubas.

\section{INTRODUÇÃO}

O século XIX foi marcado por algumas mudanças importantes no Brasil; as mulheres, que estavam restritas ao lar, passam a ser, de forma paradoxal, uma extensão deste perante a sociedade, ou seja, na esfera pública. Tornam-se modelos a serem seguidos - principalmente quando se fala das mulheres burguesas - dentro dos espaços ocupados pelas figuras masculinas a elas ligadas. Para elas, restava o "casamento como requisito fundamental de aceitação social para a mulher", como uma forma de legitimar a sua "honestidade" e "pureza" (KEHL, 2016, P. 42 e D’INCAO, 2018, p. 228). Conforme Zolin (1994, p. 8), "a dupla moral sexual e o necessário culto à beleza, partindo do pressuposto de que, por serem as mulheres puras, bondosas e de sexualidade menos desenvolvida, destinavam-se, naturalmente, às tarefas ligadas ao lar e aos papéis de esposa e de mãe".

As mulheres do século XIX, por vezes, desejam realizar escolhas, mas muitas vezes não conseguem exercê-las, em grande parte por estarem presas às expectativas sociais que são maiores que suas próprias vontades. Adentram no conflito que, conforme Schiller (apud MOST, 2001), faz parte da "dolorosa incompatibilidade entre o homem e o mundo". Daí se pode falar em uma posição social plena de tragicidade, uma vez que a livre escolha não é possível - contradição trágica primordial, segundo VidalNaquet (1999), entre o eu e o mundo; entre a vontade humana e tudo que é inevitável.

Através desta perspectiva de trágico, este trabalho foi desenvolvido tendo o objetivo de analisar a representação das personagens femininas na obra Memórias Póstumas de Brás Cubas (1881) e a forma como seus caminhos apontavam para os “destinos sem grandeza" (BOSI, 2017, p. 191).

\section{MATERIAL E MÉTODOS OU METODOLOGIA (ou equivalente)}

A metodologia utilizada para a execução do objetivo deste trabalho baseou-se na análise literária da obra machadiana, Memórias Póstumas de Brás Cubas. A partir da leitura e análise da referida obra, foi consultada a Fortuna Crítica do autor e estudos relacionados ao século XIX.

À luz dos conceitos do trágico trazidos por Vernant (1999), Pereira (2009) e Most (2001), foi elaborada a tese da tragédia social das personagens estudadas. A partir da perspectiva do conflito do homem versus o mundo, empreendeu-se a tese da mulher, seus próprios caminhos e condições sociais versus o casamento. Amparando as 
discussões acerca da obra estudada, os estudos de Barbosa (1989), Bosi (2006 e 2017), Zolin (1994), como outros autores, foram consultados.

\section{RESULTADOS E/OU DISCUSSÃO (ou Análise e discussão dos resultados)}

As trajetórias das personagens, na obra, apontam para o matrimônio como o único meio de haver estabilidade e ascensão. Marcela, Virgília, Eulália e Eugênia, mesmo provenientes de ambientes e situações diferentes, encontram um caminho comum: o lar e o possível casamento. A reação e o envolvimento delas com a situação são compatíveis com o espaço a que estão confinadas; Eulália e Eugênia, pertencentes à classe "subalterna", dependem de uma aprovação para que se casem com homens mais ricos. Eugênia, no princípio da vida adulta do narrador, é preterida; mas, ao contrário do que pensa, não o é por ser coxa de nascença, mas exatamente por ser pobre e por imputar a Cubas o impedimento de um casamento melhor, com uma mulher que lhe ofereceria mais oportunidades. Termina só, pedindo esmolas. Ao deparar-se com o matrimônio, experimenta a condição de dignidade para, finalmente, degradar-se e cair na condição de mulher livre. Eulália, por sua vez, aparecendo já ao final da vida de um Cubas desesperado e sem perspectivas, é aceita, mesmo pobre, pois é a opção que resta para que o narrador não padeça solteirão, sem ninguém que lhe cuide e lhe dê filhos. É a mulher que não cumpre o seu papel no mundo, falecendo e esvaziando a sua função. Seu trágico não se relaciona com sua precoce morte, mas com o não cumprimento do seu destino.

Virgília, por sua vez, representa a altivez da burguesia. A única, dentre as quatro, que não possui no caminho a ruína ou o casamento, pode escolher entre casar-se por amor ou por interesse social. E, ao deparar-se com a situação, não conseguindo conciliar as duas coisas em uma só, trai o amor e o matrimônio realizando o adultério como forma de ser honrada e livre. Como uma tentativa de conciliação entre si e o mundo. Marcela, por sua vez, não se reduziu ao matrimônio desde cedo. Buscou o que lhe era possível e o que lhe renderia algum fruto, mesmo que isto lhe custasse a sua reputação. Marcela foi a mulher que optou pelo segundo caminho, mas nunca descartou o retorno ao primeiro.

Estas personagens apontam para a desilusão da falta de conciliação. Suas condições sociais, as expectativas, as circunstâncias, não lhes permitiam as pazes com mundo, levando-as ao conflito das escolhas e das consequências.

\section{CONSIDERAÇÕES FINAIS (ou Conclusão)}

A ideia de tragicidade, trazida por Machado na obra estudada, à luz da perspectiva de Jean Pierre-Vernant e Pierre Vidal-Naquet (1999), nos revela a "consciência dilacerada, o sentimento das contradições que dividem o homem contra si mesmo". Com isto, entende-se que as mulheres da vida de Brás Cubas são mulheres que se permitem, à sua maneira, experimentar a contradição do papel de mulher digna e o de mulher livre, como Virgília e Marcela, ou estão presas às condições contraditórias de seu papel: sendo borboletas defeituosas, precisariam ser borboletas azuis sempre. Essas quatro mulheres encontram-se nas bifurcações dos caminhos, entre o destino social e a escolha própria. Revelam a incompatibilidade do desejo e a realidade, que as mandam em sentidos opostos. 


\section{REFERÊNCIAS}

ASSIS, Machado. Memórias Póstumas de Brás Cubas. 3 ed. São Paulo: Martin Claret, 2012.

BARBOSA, João Alexandre. A Volúpia Lasciva do Nada: uma leitura de "Memórias Póstumas de Brás Cubas”. Revista USP, maio/abril de 1989, p. 107-120. Disponível em: < http://www.revistas.usp.br/revusp/article/view/25447/27192>. Acesso em: janeiro de 2018.

BOSI, Alfredo. Brás Cubas em Três Versões: estudos machadianos. São Paulo: Companhia das Letras, 2006.

BOSI, Alfredo. História Concisa da Literatura Brasileira. 52 ed. São Paulo: Cultrix, 2017.

D’INCAO, Maria Ângela. Mulher e Família Burguesa. In: DEL PRIORE, Mary (org.). História das Mulheres no Brasil. 10ª ed. $6^{\mathrm{a}}$ reimpressão. São Paulo: Contexto, 2018, pp. 223-240.

KEHL, Maria Rita. Deslocamentos do Feminino: a mulher freudiana na passagem para a modernidade. 2 ed. São Paulo: Boitempo, 2016.

MOST, Glenn W. Da tragédia ao trágico. In: ROSENFIELD, Kathrin (org.). Filosofia e literatura: o trágico. Trad. Constança Ritter. Rio de Janeiro: Jorge Zahar. 2001, pp. 2035.

PEREIRA, Mirela Augusta. Machado de Assis: uma poética de contrastes. Dissertação (Programa de Pós-Graduação em Literatura Brasileira) - Universidade de São Paulo, São Paulo, 2009.

VERNANT, Jean-Pierre; VIDAL-NAQUET, Pierre. Mito e tragédia na Grécia antiga I e II. Trad. Anna Lia A. de Almeida Prado et al. São Paulo: Perspectiva, 1999.

ZOLIN, Lucia Osana. A Trajetória da Mulher em Contos de Machado de Assis. Dissertação (Mestrado em Biociências, Letras e Ciências Exatas) - Universidade Estadual Paulista, São José do Rio Preto, 1994. 